\title{
Modelling of Viscosity of Melts Containing Iron Oxide in Ternary Silicate Systems
}

\author{
Antonio Romero-Serrano ${ }^{a *}$ (1), Aurelio Hernández-Ramírezá, Josué López-Rodríguez ${ }^{a}$, \\ Alejandro Cruz-Ramírez ${ }^{c}$, Miguel Pérez-Labrad ${ }^{\circledR}$, Enrique Rivera-Salinas ${ }^{b}$ \\ ${ }^{a}$ Instituto Politecnico Nacional, Metallurgy and Materials, Ciudad de México, Mexico. \\ ${ }^{b}$ Consejo Nacional de Ciencia Y Tecnología (CONACyT) - Departamento de Procesos de \\ Transformación, Centro de Investigación en Quimica Aplicada (CIQA), Saltillo, Mexico. \\ 'Instituto Politecnico Nacional, Escuela Superior de Ingenieria Quimica e Industrias Extractivas, \\ Departamento de Ingenieria en Metalurgia y Materiales, Ciudad de México, Mexico. \\ ${ }^{d}$ Universidad Autonoma del Estado de Hidalgo, Academic Area of Earth Sciences and Materials, \\ Pachuca, Mexico.
}

Received: September 02, 2019; Revised: January 31, 2020; Accepted: February 04. 2020.

\begin{abstract}
The motivation of this work is to show that the structural model, which was initially used to estimate the thermodynamic properties of binary silicate systems, can be also used to estimate the viscosity of binary and ternary silicate melts in terms of temperature and composition. The model links the viscosity to the internal structure of melts through the concentration of the oxygen bridges present in the slag. A previously proposed structural thermodynamic model was used to calculate the content of oxygen bridges. The viscosity model requires only three parameters to obtain a good agreement between experimental and calculated data for the $\mathrm{SiO}_{2}-\mathrm{FeO}$ binary system and for the $\mathrm{SiO}_{2}-\mathrm{CaO}-\mathrm{FeO}$, $\mathrm{SiO}_{2}-\mathrm{MgO}-\mathrm{FeO}$ and $\mathrm{SiO}_{2}-\mathrm{MnO}-\mathrm{FeO}$ ternary systems. The viscosity of ternary systems was calculated with the model while assuming a linear function of the parameters from binary systems; however, the content of the oxygen bridges was calculated using the thermodynamic model for ternary systems.
\end{abstract}

Keywords: Viscosity, silicate structure, thermodynamic model

\section{Introduction}

The viscosity of molten slags is an important parameter for metal manufacturing since the loss of metal values may be in part attributed to mechanical entrainment in the slag phase $^{1}$. The viscosities of molten silicates are difficult to obtain experimentally due to the complexity of the procedures at a high temperature. Therefore, it is desirable to have reliable models for the prediction of viscosity in terms of the temperature and composition. The viscosity of liquid silicate systems has been studied and several models have been developed, among which some are empirical, such as the models by Riboud et al. ${ }^{2}$ and Urbain ${ }^{3}$, and others are based on the structure of silicate melts.

Reddy and Hebbar ${ }^{4}$ developed a structure-based model and predicted the viscosities of $\mathrm{SiO}_{2}-\mathrm{MO}(\mathrm{M}=\mathrm{Ca}, \mathrm{Mn}, \mathrm{Mg}, \mathrm{Fe})$ melts. Alternatively, Shu et al..$^{5}$ combined the Temkin ionic theory with the Lumsden theory in order to consider the molten slag as a system with a matrix of oxygen ions with various cations (including $\mathrm{Si}^{4+}$ ). Furthermore, Le Losq and Neuville $^{6}$ considered the viscous flow of silicate melts as governed by the cooperative re-arrangement of molecular sub-systems that involve the silicate $\mathrm{Q}^{\mathrm{n}}$ units ( $\mathrm{n}$ is the number of bridging oxygens). This model linked the $\mathrm{Q}^{\mathrm{n}}$ unit fractions to the melt configurational entropy at the glass transition temperature and, finally, to its viscosity. Kondratiev and $\mathrm{Jak}^{7}$ used a model to link the slag viscosity to the internal structure of melts through the concentrations of various anion/cation structural units. The concentrations of structural units were

*e-mail: romeroipn@hotmail.com equivalent to the second-nearest neighbor bond concentrations calculated by the quasi-chemical thermodynamic model.

The present model uses the structural model to estimate the concentration of the types of oxygen in binary and ternary silicate systems. This structural model has been used to calculate the thermodynamic properties and the phase diagrams for binary and ternary systems $\mathrm{s}^{8,9}$ as well as to estimate the sulphide capacity of binary silicate melts. The model has also been used to estimate the molar volume of binary and ternary silicates ${ }^{10}$ and the viscosity of the binary and ternary silicate of the system $\mathrm{SiO}_{2}-\mathrm{CaO}-\mathrm{MgO}-\mathrm{MnO}-\mathrm{Na}_{2} \mathrm{O}^{11}$. Recently, Wu et al. ${ }^{12,13}$ developed a viscosity model where the oxygen partial pressure was taken into account, and the structural roles of $\mathrm{FeO}$ and $\mathrm{Fe}_{2} \mathrm{O}_{3}$ in determining the slag viscosity were assessed. In this model, the silicate structure was described by means of a non-ideal associate solution to describe the Gibbs energy of the liquid phase.

In the present work, we use the structural model to estimate the viscosity of the $\mathrm{SiO}_{2}-\mathrm{FeO}$ binary system and the viscosity of the $\mathrm{SiO}_{2}-\mathrm{CaO}-\mathrm{FeO}, \mathrm{SiO}_{2}-\mathrm{MgO}-\mathrm{FeO}$ and $\mathrm{SiO}_{2}-\mathrm{MnO}-\mathrm{FeO}$ ternary systems. It is worth mentioning that the $\mathrm{SiO}_{2}-\mathrm{FeO}$ system is a base for many metallurgical slags, particularly steelmaking, copper smelting, converting and slag cleaning. The motivation of this work is to show that the structural model, which was initially used to estimate the thermodynamic properties and phase diagrams of binary $\mathrm{SiO}_{2}-\mathrm{MO}$ systems ( $\mathrm{M}=\mathrm{Ca}, \mathrm{Mn}, \mathrm{Fe}$, etc.), can be also used to estimate other physicochemical properties, such as molar volume and viscosity, which depend on the structure of the molten silicates. 


\section{The Model}

\subsection{Thermodynamic Model}

The model, as it has been mentioned in a previous work ${ }^{11}$, is based on the silicate structure where the basic building block is the $\mathrm{Si}-\mathrm{O}$ tetrahedron, in which one $\mathrm{Si}^{4+}$ cation is surrounded by four $\mathrm{O}-$ ions. The silica network structure breaks down with the addition of basic oxides, which gives it a more depolymerized structure. These structural models consider three types of oxygen: (1) bridging oxygen bonded to two silicon atoms $\left(\mathrm{O}^{\circ}\right),(2)$ non-bridging oxygen bonded only to one silicon atom $\left(\mathrm{O}^{-}\right)$and (3) free oxygen bonded to no silicon atom $\left(\mathrm{O}^{2-}\right)$ :

$$
\begin{gathered}
\mathrm{Si}-\mathrm{O}-\mathrm{Si}+\mathrm{MO}=\mathrm{Si}-\mathrm{O}^{\mathrm{M}} \mathrm{O}-\mathrm{Si} \\
\mathrm{O}^{\mathrm{o}}+\mathrm{O}^{2-}=2 \mathrm{O}^{-}
\end{gathered}
$$

In a binary solution $\mathrm{SiO}_{2}-\mathrm{MO}\left(\mathrm{M}=\mathrm{Ca}, \mathrm{Fe}, \mathrm{Na}_{2}\right.$, etc.), the parameters $\mathrm{N}_{\mathrm{O}^{2-}}, \mathrm{N}_{\mathrm{O}^{-}}$and $\mathrm{N}_{\mathrm{O}^{\circ}}$ represent the number of moles of the various oxygen species per mole of solution $\left(\mathrm{n}_{\mathrm{MO}}+\mathrm{n}_{\mathrm{SiO} 2}\right)$. It is assumed that every silicon atom is bonded to four oxygen atoms. Thus, mass balance considerations require the following:

$$
\begin{aligned}
& \mathrm{N}_{\mathrm{O}^{\circ}}=2 \mathrm{X}_{\mathrm{SiO}_{2}}-\frac{\mathrm{N}_{\mathrm{O}^{-}}}{2} \\
& \mathrm{~N}_{\mathrm{O}^{2-}}=\mathrm{X}_{\mathrm{MO}}-\frac{\mathrm{N}_{\mathrm{O}^{-}}}{2}
\end{aligned}
$$

where $\mathrm{X}_{\mathrm{SiO}_{2}}$ and $\mathrm{X}_{\mathrm{MO}}$ are the mole fractions of the oxides. The configurational entropy $\left(\mathrm{S}^{\mathrm{c}}\right)$ is physically related to the number of ways in which particles themselves can be distributed in space. $\mathrm{S}^{\mathrm{c}}$ is calculated through the multiplicity of the random distribution of the $\mathrm{Si}$ atoms and $\mathrm{O}^{2-}$ ions on the sites $\left(\Omega_{1}\right)$ and the multiplicity of the random distribution of the $\mathrm{N}_{\mathrm{O}^{\circ}}$ bridging oxygen atoms over the number of moles of neighboring Si-Si pairs positions $\left(\Omega_{2}\right)$.

$$
\mathrm{S}^{\mathrm{c}}=\frac{\mathrm{R}}{\mathrm{N}^{\mathrm{o}}} \ln \left[\Omega_{1} \Omega_{2}\right]
$$

where $\mathrm{R}$ is the gas constant and $\mathrm{N}^{\circ}$ is Avogadro's number. The structural model assumes that the depolymerization reaction, Equation 2, is associated with the Gibbs energy change containing an enthalpic $(\omega)$ and entropic $(\varepsilon)$ term:

$$
\Delta \mathrm{H}-\mathrm{TS}^{\mathrm{nc}}=\left(\frac{\mathrm{N}_{\mathrm{O}^{-}}}{2}\right) \omega-\mathrm{T}\left(\frac{\mathrm{N}_{\mathrm{O}^{-}}}{2}\right) \varepsilon
$$

where $\Delta \mathrm{H}$ is the change of enthalpy of the breaking bridge process, $\mathrm{S}^{\mathrm{nc}}$ is the non-configurational entropy and $\mathrm{T}$ is the absolute temperature. Finally, $\omega$ and $\varepsilon$ are expanded as polynomials:

$$
\begin{array}{r}
\omega=\omega_{0}+\omega_{1} \mathrm{X}_{\mathrm{SiO}_{2}}+\omega_{2} \mathrm{X}_{\mathrm{SiO}_{2}}^{2}+\ldots \\
\varepsilon=\varepsilon_{0}+\varepsilon_{1} \mathrm{X}_{\mathrm{SiO}_{2}}+\varepsilon_{2} \mathrm{X}_{\mathrm{SiO}_{2}}^{2}+\ldots
\end{array}
$$

The coefficients $\omega_{i}$ and $\varepsilon_{i}$ are the parameters of the thermodynamic model, which are obtained by the optimization of data. When given a composition $\mathrm{X}_{\mathrm{SiO}_{2}}$ and the values of the parameters $\omega_{\mathrm{i}}$ and $\varepsilon_{\mathrm{i}}$, the actual value of $\mathrm{N}_{\mathrm{O}^{-}}$can be calculated by minimizing the Gibbs energy at constant $\mathrm{X}_{\mathrm{SiO}_{2}}, \omega$ and $\varepsilon$ :

$$
\Delta \mathrm{G}=\Delta \mathrm{H}-\mathrm{T}\left(\mathrm{S}^{\mathrm{c}}+\mathrm{S}^{\mathrm{nc}}\right)
$$

Table 1 shows the parameters $\omega_{\mathrm{i}}$ and $\varepsilon_{\mathrm{i}}$ for $\mathrm{SiO}_{2}-\mathrm{FeO}$, $\mathrm{SiO}_{2}-\mathrm{CaO}, \mathrm{SiO}_{2}-\mathrm{MgO}$ and $\mathrm{SiO}_{2}-\mathrm{MnO}$ binary systems ${ }^{8}$, and Figure 1 shows the concentrations of oxygen bridges $\left(\mathrm{O}^{\circ}\right)$ calculated by the model at $1673 \mathrm{~K}$ for these systems. This Figure also shows that the efficiency in breaking oxygen bridges increases in the order $\mathrm{FeO}<\mathrm{MnO}<\mathrm{MgO}<\mathrm{CaO}$.

To expand the model for ternary systems, we considered 5 kinds of oxygen ${ }^{9}$. Let us consider the general $\mathrm{SiO}_{2}-\mathrm{AO}-\mathrm{BO}$ ternary system where $\mathrm{A}$ and $\mathrm{B}$ are divalent cations, such as $\mathrm{Ca}^{2+}$ and $\mathrm{Fe}^{2+}$ :

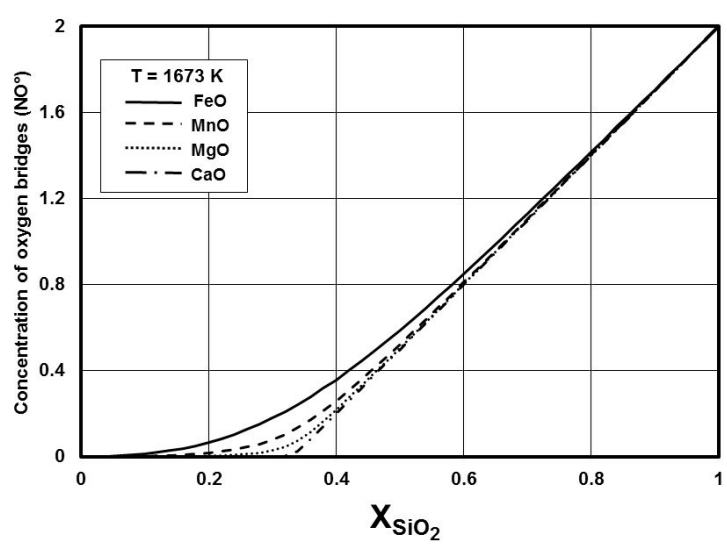

Figure 1. Concentration of oxygen bridges in the $\mathrm{SiO}_{2}-\mathrm{MO}$ $(\mathrm{M}=\mathrm{Fe}, \mathrm{Mn}, \mathrm{Mg}, \mathrm{Ca})$ system calculated at $1673 \mathrm{~K}$ by the structural model.

Table 1. Parameters for the thermodynamic model of binary silicate systems ${ }^{8}$.

\begin{tabular}{cl}
\hline System & \multicolumn{1}{c}{ Expression of $\omega$ and $\varepsilon$} \\
\hline $\mathrm{SiO}_{2}-\mathrm{FeO}$ & $\omega=6770-122724 \mathrm{X}_{\mathrm{SiO} 2}+183040 \mathrm{X}_{\mathrm{SiO} 2}^{2}+106539 \mathrm{X}_{\mathrm{SiO} 2}^{4} \mathrm{~J} / \mathrm{mol}$ \\
& $\varepsilon=-34.59 \mathrm{X}_{\mathrm{SiO} 2}+87.366 \mathrm{X}_{\mathrm{SiO} 2}^{3} \mathrm{~J} / \mathrm{mol} \mathrm{K}$ \\
\hline $\mathrm{SiO}_{2}-\mathrm{CaO}$ & $\omega=-57738-258739 \mathrm{X}_{\mathrm{SiO} 2}+262548 \mathrm{X}_{\mathrm{SiO} 2}^{2}+89325 \mathrm{X} \mathrm{SiO} 2^{6} \mathrm{~J} / \mathrm{mol}$ \\
& $\varepsilon=-35.5 \mathrm{X}_{\mathrm{SiO} 2}+70.71 \mathrm{X}_{\mathrm{SiO} 2}^{4} \mathrm{~J} / \mathrm{mol} \mathrm{K}$ \\
\hline $\mathrm{SiO}_{2}-\mathrm{MgO}$ & $\omega=-51140-76333 \mathrm{X}_{\mathrm{SiO} 2}+245570 \mathrm{X}_{\mathrm{SiO} 2}^{3} \mathrm{~J} / \mathrm{mol}$ \\
& $\varepsilon=-47.99 \mathrm{X}_{\mathrm{SiO} 2}+94.164 \mathrm{X}_{\mathrm{SiO} 2}^{3} \mathrm{~J} / \mathrm{mol} \mathrm{K}^{-}$ \\
\hline $\mathrm{SiO}_{2}-\mathrm{MnO}$ & $\omega=-56143-1791 \mathrm{X}_{\mathrm{SiO} 2}+116820 \mathrm{X}_{\mathrm{SiO} 2}^{3} \mathrm{~J} / \mathrm{mol}$ \\
\hline
\end{tabular}


1. $\mathrm{O}^{\circ}$ : Oxygen bridge

2. $\mathrm{O}_{\mathrm{A}}^{2-}$ : 'Free oxygen ions' introduced in the system by the $\mathrm{AO}$ species

3. $\mathrm{O}_{\mathrm{B}}^{2-}$ : 'Free oxygen ions' introduced in the system by the $\mathrm{BO}$ species

4. $\mathrm{O}_{\mathrm{A}}^{-}$: Broken bridges for the $\mathrm{AO}$ species

5. $\mathrm{O}_{\mathrm{B}}^{-}$: Broken bridges for the $\mathrm{BO}$ species

There are two depolymerization reactions, which are given as follows:

$$
\begin{array}{ll}
\mathrm{Si}-\mathrm{O}-\mathrm{Si}+\mathrm{AO}=\mathrm{Si}-\mathrm{O}^{\mathrm{A}} \mathrm{O}-\mathrm{Si} & (\omega-\varepsilon \mathrm{T})_{\mathrm{AO}} \\
\mathrm{Si}-\mathrm{O}-\mathrm{Si}+\mathrm{BO}=\mathrm{Si}-\mathrm{O}^{\mathrm{B}} \mathrm{O}-\mathrm{Si} \quad(\omega-\varepsilon \mathrm{T})_{\mathrm{BO}}
\end{array}
$$

The mass balance considerations now require the following:

$$
\begin{gathered}
\mathrm{N}_{\mathrm{O}^{\circ}}=2 \mathrm{X}_{\mathrm{SiO}_{2}}-\frac{\mathrm{N}_{\mathrm{O}_{\mathrm{A}}^{-}}+\mathrm{N}_{\mathrm{O}_{\mathrm{B}}^{-}}}{2} \\
\mathrm{~N}_{\mathrm{O}_{\mathrm{A}}^{2-}}=\mathrm{X}_{\mathrm{AO}}-\frac{\mathrm{N}_{\mathrm{O}_{\mathrm{A}}^{-}}}{2} \\
\mathrm{~N}_{\mathrm{O}_{\mathrm{B}}^{2-}}=\mathrm{X}_{\mathrm{BO}}-\frac{\mathrm{N}_{\mathrm{O}_{\mathrm{B}}^{-}}}{2}
\end{gathered}
$$

The expression of the configurational entropy is obtained by making two statistical distributions:

$$
\mathrm{S}^{\mathrm{c}}=\mathrm{S}_{\mathrm{I}}^{\mathrm{c}}+\mathrm{S}_{\mathrm{II}}^{\mathrm{c}}
$$

where $\mathrm{S}_{\mathrm{I}}^{\mathrm{c}}$ is estimated through the distribution of $\mathrm{O}_{\mathrm{A}}^{2-}, \mathrm{O}_{\mathrm{B}}^{2-}$ and $\mathrm{Si}$ in a quasi-lattice and $\mathrm{S}_{\mathrm{II}}^{\mathrm{c}}$ is estimated through the distribution of $\mathrm{O}^{\circ}$ over the neighboring Si-Si pairs. The excess free energy expression for the ternary system is obtained with the addition of the interaction energy terms $(\omega-\varepsilon T)$ for each bridge-breaking reaction, Equations 10 and 11, which are known in the two binary systems $\left(\mathrm{SiO}_{2}-\mathrm{AO}\right.$ and $\left.\mathrm{SiO}_{2}-\mathrm{BO}\right)$ from the binary optimizations. This expression must also include the contribution of the excess free energy for the $\mathrm{AO}-\mathrm{BO}$ binary system, $\mathrm{G}_{\mathrm{AO}-\mathrm{BO}}^{\mathrm{E}}$, which is multiplied by the fraction of free oxygen ions in the quasi-lattice whose sites are occupied by $\mathrm{O}^{2-}$ ions and $\mathrm{Si}$ atoms.

\subsection{Viscosity Model}

\section{Binary Systems}

In the present study, the viscosity for binary $\mathrm{SiO}_{2}-\mathrm{MO}$ systems ( $\mathrm{M}=\mathrm{Ca}, \mathrm{Mg}, \mathrm{Fe}, \mathrm{Mn}, \mathrm{Na}_{2}$, etc.) is expressed as follows:

$$
\ln \eta=\mathrm{A}+\frac{\mathrm{B}}{\mathrm{T}}+\mathrm{CN}_{\mathrm{O}^{\circ}}
$$

The temperature dependence of viscosity is described by the Arrhenius equation, where $\eta$ is viscosity in $\mathrm{Pa} \cdot \mathrm{s}$, $\mathrm{A}$ is the natural logarithm of the pre-exponential term,
$B$ is the activation energy over the gas constant (E/R), and $\mathrm{T}$ is the absolute temperature. It has been shown in a previous work ${ }^{11}$ that, at a given temperature, $\ln (\eta)$ is nearly a linear function of the concentration of oxygen bridges $\left(\mathrm{N}_{\mathrm{O}^{\circ}}\right)$. Parameter $\mathrm{C}$ in Equation 16 gives to the linear relationship between experimentally calculated $\ln (\eta)$ and the concentration of oxygen bridges $\left(\mathrm{N}_{\mathrm{O}^{\circ}}\right)$ calculated by the structural model.

It is noteworthy that even though there are three types of oxygens in the silicate structure $\left(\mathrm{O}^{\circ}, \mathrm{O}^{-}\right.$and $\left.\mathrm{O}^{2-}\right)$ in a binary system, the viscosity model in Equation 16 is expressed only in terms of the amount of the oxygen bridges $\left(\mathrm{N}_{0^{\circ}}\right)$ since the other two types of oxygens are related directly to $\mathrm{N}_{\mathrm{O}}$ through the mass balance given in Equations 3 and 4.

The results show that only three parameters were needed to calculate the viscosity in terms of both composition and temperature in binary silicate systems. The values of these parameters for the $\mathrm{SiO}_{2}-\mathrm{MO}(\mathrm{M}=\mathrm{Fe}, \mathrm{Mn}, \mathrm{Mg}$ and $\mathrm{Ca})$ binary systems were obtained by the regression of viscosity data, and the results are shown in Table 2 .

\section{Ternary Systems}

The model is expanded for ternary silicate systems using a linear relationship of the model parameters of the binary silicate systems. That is, if $Y$ represents any of the fitting binary parameters $\mathrm{A}, \mathrm{B}$, or $\mathrm{C}$ of Equation $16, \mathrm{Z}$ in the $\mathrm{SiO}_{2}-\mathrm{AO}-\mathrm{BO}$ ternary system is obtained as follows:

$$
\mathrm{Z}=\left[\frac{\mathrm{X}_{\mathrm{AO}}}{\mathrm{X}_{\mathrm{AO}}+\mathrm{X}_{\mathrm{BO}}}\right] \mathrm{Y}_{\mathrm{SiO}_{2}-\mathrm{AO}}+\left[\frac{\mathrm{X}_{\mathrm{BO}}}{\mathrm{X}_{\mathrm{AO}}+\mathrm{X}_{\mathrm{BO}}}\right] \mathrm{Y}_{\mathrm{SiO}_{2}-\mathrm{BO}}
$$

However, the concentration of oxygen bridges $\left(\mathrm{N}_{\mathrm{O}^{\circ}}\right)$ of Equation 16 is calculated with the structural model for ternary systems.

\section{Modelling Results and Discussion}

\section{1 $\mathrm{SiO}_{2}-\mathrm{FeO}$ Binary System}

The viscosity model for the binary systems was used in a previous work for the $\mathrm{SiO}_{2}-\mathrm{MnO}, \mathrm{SiO}_{2}-\mathrm{MgO}$ and $\mathrm{SiO}_{2}-\mathrm{CaO}$ systems. In this work, we applied the model to the $\mathrm{SiO}_{2}-\mathrm{FeO}$ system. Figures 2 and 3 show the experimental ${ }^{14-20}$ and calculated values of viscosity of the $\mathrm{SiO}_{2}-\mathrm{FeO}$ system at 1573 and $1673 \mathrm{~K}$, respectively, where it can be observed that they are in good agreement.

The $\mathrm{SiO}_{2}-\mathrm{FeO}$ is one of the systems with a considerable amount of viscosity experimental data. Myslevic et al. ${ }^{14}$ used the rotating-cylinder method to measure the viscosities of $\mathrm{SiO}_{2}-\mathrm{FeO}$ slags using pure iron, crucibles and bobs, to minimize the chemical attack of slags with high $\mathrm{FeO}$ contents.

Table 2. Values of model parameters for different binary silicate systems.

\begin{tabular}{cccc}
\hline System & $\mathbf{A}$ & $\mathbf{B}$ & $\mathbf{C}$ \\
\hline $\mathrm{SiO}_{2}-\mathrm{FeO}$ & -8.33278 & 6706.76 & 4.8261 \\
\hline $\mathrm{SiO}_{2}-\mathrm{MnO}$ & -12.4586 & 14048.62 & 6.0765 \\
\hline $\mathrm{SiO}_{2}-\mathrm{MgO}$ & -14.5122 & 21061.97 & 4.1265 \\
\hline $\mathrm{SiO}_{2}-\mathrm{CaO}$ & -13.2523 & 18429.96 & 4.0069 \\
\hline
\end{tabular}


Zhang and Jahanshahi ${ }^{15}$ reported that unlike the viscosity of other binary silicate systems which increase monotonically with an increase in silica content, the viscosity of the

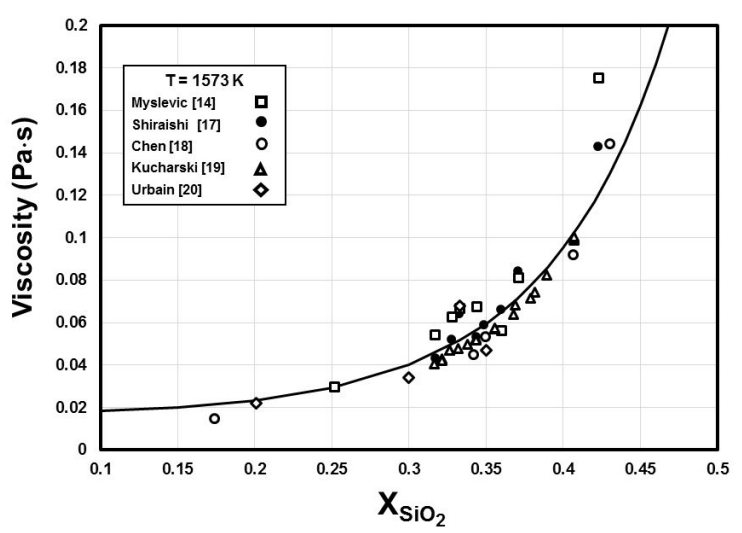

Figure 2. Calculated (line) and experimental (points) viscosities at $1573 \mathrm{~K}$ of $\mathrm{SiO}_{2}-\mathrm{FeO}$ melts.

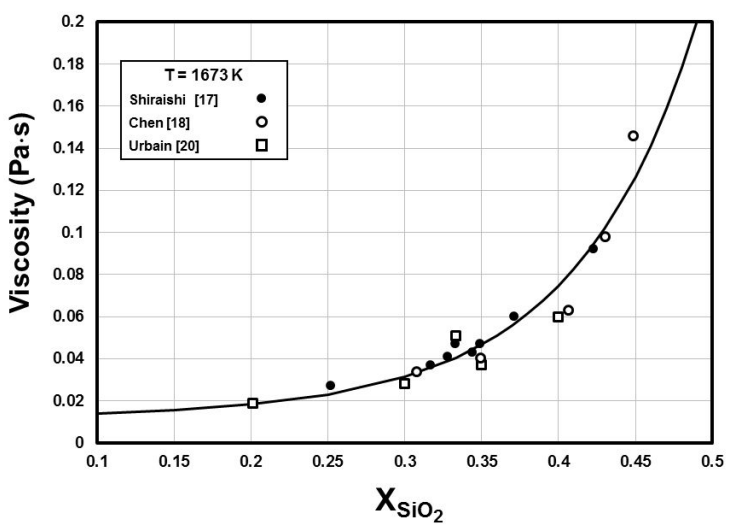

Figure 3. Calculated (line) and experimental (points) viscosities at $1673 \mathrm{~K}$ of $\mathrm{SiO}_{2}-\mathrm{FeO}$ melts.
$\mathrm{FeO}-\mathrm{SiO}_{2}$ system exhibits a maximum at about the fayalite $\left(\mathrm{FeO} \cdot 2 \mathrm{SiO}_{2}\right.$ ) composition, and the values of maximum decrease with increase in temperature. A huge peak was reported in the studies by Röntgen et al. ${ }^{16}$, and Shiraishi et al. ${ }^{17}$, which found small but sharp humps on viscosity near the fayalite composition.

Chen et al. ${ }^{18}$ measured the viscosity of the $\mathrm{SiO}_{2}-\mathrm{FeO}$ system in equilibrium with iron using a rotational rheometer and Mo crucible and spindle under Ar gas. This work showed that there was no maximum viscosity in the fayalite composition in this system. Kucharski et al. ${ }^{19}$ measured the viscosity of $\mathrm{SiO}_{2}-\mathrm{FeO}$ under a higher oxygen potential away from iron saturation and the peak at the fayalite composition was not observed.

Table 3 lists the calculated and experimental ${ }^{14,17,19,20}$ results obtained at $1573 \mathrm{~K}$ between 0.201 and 0.423 mole fraction of $\mathrm{SiO}_{2}$, whereas Table 4 shows the calculated and experimental results obtained at $1673 \mathrm{~K}$ by Shiraishi et al. ${ }^{17}$ and Urbain et al. ${ }^{20}$ Even though Shiraishi et al. ${ }^{17}$ reported on an average of $3.5 \mathrm{wt} . \% \mathrm{Fe}_{2} \mathrm{O}_{3}$ and $0.86 \mathrm{wt} \%$ elemental $\mathrm{Fe}$, the values calculated by the present model were obtained by assuming that the melt was made up of only $\mathrm{SiO}_{2}$ and $\mathrm{FeO}$, i.e., $\mathrm{FeO}$ and small quantities of $\mathrm{Fe}_{2} \mathrm{O}_{3}$ were both considered as FeO. Tables 3 and 4 also show the concentration of oxygen bridges $\left(\mathrm{N}_{\mathrm{O}^{\circ}}\right)$ as calculated by the thermodynamic structural model, which was used in Equation 16 to estimate the viscosity of this binary system.

Figure 4 shows a comparison between the estimated and measured values for system $\mathrm{SiO}_{2}-\mathrm{FeO}$ at $1573 \mathrm{~K}$ and $1673 \mathrm{~K}$. The mean deviation $\Delta$, as calculated by Equation 18 , is about $11.7 \%$.

$$
\Delta=\frac{1}{N} \sum_{i=1}^{N} \frac{\left(\eta_{\text {cal }}-\eta_{\exp }\right)}{\eta_{\exp }} 100
$$

where $\eta_{\text {cal }}$ and $\eta_{\text {exp }}$ are the calculated and experimental viscosities, respectively, $\mathrm{N}$ is the total number of values.

Table 3. Experimental and calculated viscosities of the $\mathrm{SiO}_{2}-\mathrm{FeO}$ system at $1573 \mathrm{~K}$, in Pa.s.

\begin{tabular}{|c|c|c|c|c|c|c|}
\hline $\mathbf{X}_{\mathrm{SiO} 2}$ & $\mathrm{NO}^{\circ}$ & Shiraishi et al. ${ }^{17}$ & Myslevic et al. ${ }^{14}$ & 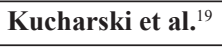 & Urbain et al. ${ }^{20}$ & Calculated \\
\hline 0.2010 & 0.0662 & - & - & - & 0.022 & 0.0235 \\
\hline 0.2520 & 0.1150 & 0.030 & 0.0296 & - & - & 0.0298 \\
\hline 0.3000 & 0.1771 & - & - & - & 0.034 & 0.0402 \\
\hline 0.3162 & 0.2017 & - & - & 0.0406 & - & 0.0452 \\
\hline 0.3170 & 0.2029 & 0.043 & 0.0542 & - & - & 0.0455 \\
\hline 0.3212 & 0.2096 & - & - & 0.0423 & - & 0.0470 \\
\hline 0.3280 & 0.2207 & 0.052 & 0.0625 & - & - & 0.0496 \\
\hline 0.3330 & 0.2290 & 0.064 & 0.0667 & 0.0476 & 0.068 & 0.0516 \\
\hline 0.3440 & 0.2479 & 0.053 & 0.0675 & - & - & 0.0565 \\
\hline 0.3490 & 0.2568 & 0.059 & - & - & - & 0.0590 \\
\hline 0.3500 & 0.2586 & - & - & - & 0.047 & 0.0595 \\
\hline 0.3558 & 0.2691 & & - & 0.0576 & - & 0.0626 \\
\hline 0.3600 & 0.2768 & 0.066 & 0.0563 & - & - & 0.0650 \\
\hline 0.3676 & 0.2911 & - & - & 0.0640 & - & 0.0697 \\
\hline 0.3690 & 0.2937 & - & - & 0.0683 & - & 0.0705 \\
\hline 0.3710 & 0.2976 & 0.084 & 0.0813 & - & - & 0.0719 \\
\hline 0.3789 & 0.3129 & - & - & 0.0714 & - & 0.0774 \\
\hline 0.3892 & 0.3335 & - & - & 0.0822 & - & 0.0855 \\
\hline 0.4068 & 0.3700 & - & - & 0.0996 & - & 0.1019 \\
\hline 0.4230 & 0.4051 & 0.143 & 0.1750 & - & - & 0.1207 \\
\hline
\end{tabular}


Table 4. Experimental and calculated viscosities of the $\mathrm{SiO}_{2}-\mathrm{FeO}$ system at $1673 \mathrm{~K}$, in $\mathrm{Pa} \cdot \mathrm{s}$.

\begin{tabular}{ccccc}
\hline $\mathbf{X}_{\text {SiO2 }}$ & NO $^{\circ}$ & Shiraishi et al. ${ }^{17}$ & Urbain et al $^{20}$ & Calculated \\
\hline 0.201 & 0.0674 & - & 0.019 & 0.0183 \\
\hline 0.252 & 0.1169 & 0.027 & - & 0.0233 \\
\hline 0.300 & 0.1797 & - & 0.028 & 0.0315 \\
\hline 0.317 & 0.2056 & 0.037 & - & 0.0357 \\
\hline 0.328 & 0.2234 & 0.041 & 0.051 & 0.0389 \\
\hline 0.333 & 0.2317 & 0.047 & - & 0.0405 \\
\hline 0.344 & 0.2506 & 0.043 & - & 0.0444 \\
\hline 0.349 & 0.2594 & 0.047 & 0.037 & 0.0463 \\
\hline 0.350 & 0.2612 & - & - & 0.0467 \\
\hline 0.371 & 0.3001 & 0.060 & 0.06 & 0.0564 \\
\hline 0.400 & 0.378 & - & - & 0.0821 \\
\hline 0.423 & 0.407 & 0.092 & 0.0944
\end{tabular}

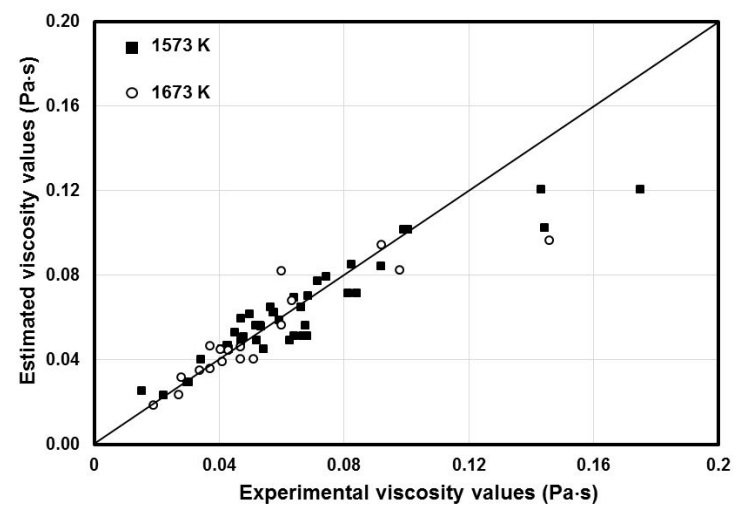

Figure 4. Comparison of the calculated and experimental ${ }^{(14,17-20)}$ viscosities for the $\mathrm{SiO}_{2}-\mathrm{FeO}$ system.

Dingwell ${ }^{21}$ has shown that an increase in the $\mathrm{Fe}^{3+} / \mathrm{Fe}^{2+}$ ratio led to an increased viscosity. Wu et al. ${ }^{12,13}$ reported that the local viscosity maximum, around the fayalite composition in the $\mathrm{SiO}_{2}-\mathrm{FeO}$ melts, is related to the charge compensation of $\mathrm{FeO}_{2}{ }^{-}$by $\mathrm{Fe}^{2+}$ and is dependent on temperature and oxygen partial pressure.

Like the other proposed models ${ }^{4,15}$, the present model has a drawback as it does not show the peak in the viscosity composition curve for melts containing approximately $30 \mathrm{~mol} \%$ of $\mathrm{SiO}_{2}$. However, this phenomenon was not experimentally observed by all the researchers who studied this system and any other binary metal-oxide silicate system; thus, further experimental verification is needed in future works. There was a good agreement between the experimental and calculated data even though the model does not consider some intrinsic physicochemical properties of metal oxides explicitly, such as the electronegativity or ionic radii of metal ions.

The current model has been applied with reasonable success to describe the thermodynamic properties and phase diagrams of binary silicate systems $\mathrm{SiO}_{2}-\mathrm{MO}$ $\left(\mathrm{M}=\mathrm{Ca}, \mathrm{Mg}, \mathrm{Fe}, \mathrm{Na}_{2}\right.$, etc.). However, one limitation of the model is that it cannot deal with systems with amphoteric oxides $\left(\mathrm{Fe}_{2} \mathrm{O}_{3}\right.$ and $\left.\mathrm{Al}_{2} \mathrm{O}_{3}\right)$, which act as either network formers or network modifiers depending on the composition. $\mathrm{Fe}^{3+}$ and $\mathrm{Al}^{3+}$ require a charge compensation in the network to form a building block such as the $\mathrm{Si}-\mathrm{O}$ tetrahedron, where one $\mathrm{Si}^{4+}$ cation is surrounded by four $\mathrm{O}-$ ions.

\subsection{Ternary Systems}

The viscosity of $\mathrm{SiO}_{2}-\mathrm{CaO}-\mathrm{FeO}$ melts was measured at $1573 \mathrm{~K}$ by Kucharski et al. ${ }^{19}$ and Shidar et al. ${ }^{22}$ and at $1673 \mathrm{~K}$ by Sridhar et al. ${ }^{22}$, Ji et al. ${ }^{23}$ and Johannsen and Wiese ${ }^{24}$. Most of these experiments were carried out at a relatively low oxygen partial pressure of $6 \times 10^{-11}$ atm $\left(6.08 \times 10^{-6} \mathrm{~Pa}\right)$; thus, it was reasonable to treat the system as a ternary $\mathrm{SiO}_{2}-\mathrm{CaO}-\mathrm{FeO}$. The viscosities predicted by the model were compared with these studies in Figures 5 and 6 . These Figures show the limiting liquidus curve at the temperatures considered. The model reproduced the measured viscosities within the scatter of the experimental data from different authors. The mean deviation $\Delta$ that was calculated for the $\mathrm{SiO}_{2}-\mathrm{CaO}-\mathrm{FeO}$ was about $26 \%$ and $31 \%$ at $1573 \mathrm{~K}$ and $1673 \mathrm{~K}$, respectively.

Several models, such as Urbain's model ${ }^{3}$, considered the viscosity of the ternary silicate system to be a linear function of the viscosity of the binary silicate systems, which may not be justified in all the systems and all the compositions. This is because, in these ternary silicate systems, there are two network modifying metallic oxides and the ideal mixing assumption is not enough to account for the property changes with composition.

The present viscosity model is quite simple with only three parameters for each binary system. The oxygen bridges parameter $\left(\mathrm{N}_{\mathrm{O}^{\circ}}\right)$ implicitly considered the effect of both temperature and composition. We did not include additional adjusted parameters for ternary systems, which is why the mean deviations for these systems were higher than those of the binary systems.

The present model for ternary systems dealt with the effect on viscosity of substituting one basic metal oxide with another. Figure 7 shows the estimated and experimental ${ }^{19,22}$ viscosities in the $\mathrm{SiO}_{2}-\mathrm{CaO}-\mathrm{FeO}$ system at $1573 \mathrm{~K}$ and $\mathrm{X}_{\mathrm{SiO} 2}=0.327$. Thus, it is clear that the viscosity was higher than that of the linear extrapolation.

It has been reported ${ }^{11}$ that this model predicts a maximum value in the viscosity of ternary systems. For the $\mathrm{SiO}_{2}-\mathrm{CaO}-\mathrm{FeO}$ system, this maximum can be explained because $\mathrm{FeO}$ is not as efficient in breaking the oxygen bridges as $\mathrm{CaO}$; furthermore, when $\mathrm{CaO}$ is replaced by $\mathrm{FeO}$, the amount of oxygen bridges $\left(\mathrm{NO}^{\circ}\right)$ and viscosity increases as compared with the linear extrapolation results. Figure 8 shows the concentration of oxygen bridge $\left(\mathrm{N}_{\mathrm{O}^{\circ}}\right)$ in terms 


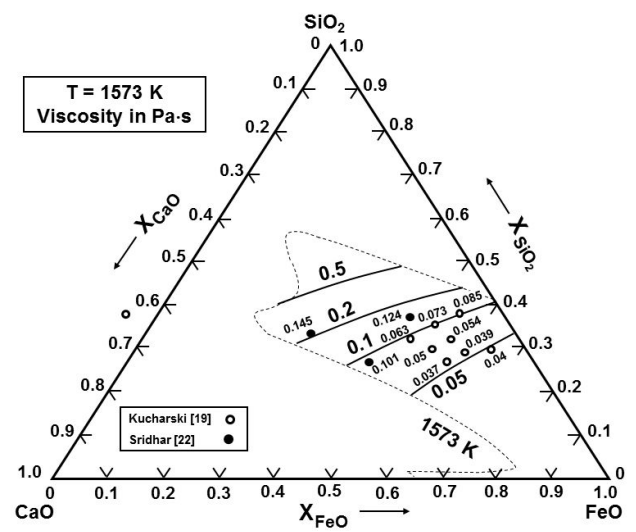

Figure 5. Isoviscosity curves $(\mathrm{Pa} \cdot \mathrm{s})$ of $\mathrm{SiO}_{2}-\mathrm{CaO}-\mathrm{FeO}$ melts at $1573 \mathrm{~K}$.

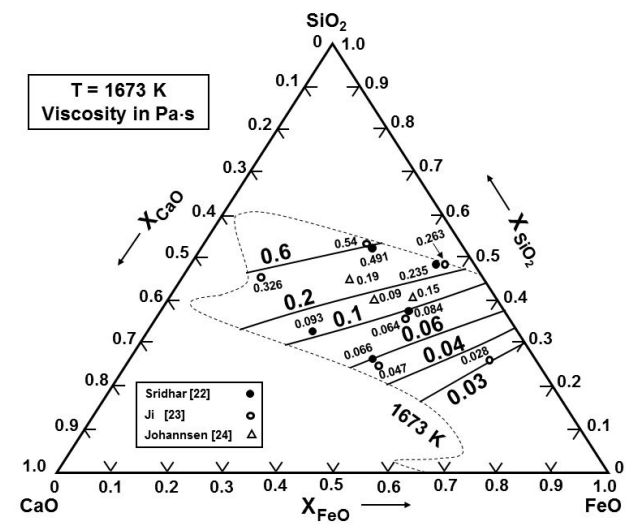

Figure 6. Isoviscosity curves $(\mathrm{Pa} \cdot \mathrm{s})$ of $\mathrm{SiO}_{2}-\mathrm{CaO}-\mathrm{FeO}$ melts at $1673 \mathrm{~K}$.

of composition for the $\mathrm{SiO}_{2}-\mathrm{CaO}-\mathrm{FeO}$ system at $1573 \mathrm{~K}$ and $\mathrm{X}_{\mathrm{SiO} 2}=0.327$. Figures 7 and 8 show that the $\mathrm{N}_{\mathrm{O}^{\circ}}$ and viscosity of the ternary system cannot be linearly extrapolated from the results of the binary systems. However, additional experimental results are required to confirm the maximum viscosity values predicted by this model.

Shidar et al. ${ }^{22}$ and Ji et al. ${ }^{25}$ measured the viscosity values of the $\mathrm{SiO}_{2}-\mathrm{MnO}-\mathrm{FeO}$ system using the rotating cylinder method with an iron spindle and crucible to ensure all $\mathrm{Fe}$ was in valence of $2+$. Comparisons between the estimated values and measured values for this system are shown in Figures 9 and 10 at $1673 \mathrm{~K}$ and $1723 \mathrm{~K}$, respectively. The mean deviation $\Delta$ calculated for the $\mathrm{SiO}_{2}-\mathrm{MnO}-\mathrm{FeO}$ system was about $29 \%$ and $34 \%$ at $1673 \mathrm{~K}$ and $1723 \mathrm{~K}$, respectively.

Kucharski et al. ${ }^{19}$, studied the $\mathrm{SiO}_{2}-\mathrm{MgO}-\mathrm{FeO}$ in a rather limited composition range in the $\mathrm{SiO}_{2}-\mathrm{FeO}$ rich side with $\mathrm{X}_{\mathrm{SiO} 2}$ from 0.3 to 0.38 , and a narrow temperature range of 1543 to $1623 \mathrm{~K}$. In Figure 11, the experimental data at $1623 \mathrm{~K}$ and calculated results are shown; as can be seen, the liquid region is very small and measurements are very close to the liquidus. This Figure also presents some experimental values reported by Sridhar et al..$^{22}$ and Ji et al..$^{25}$ The mean deviation $\Delta$ that was calculated for the $\mathrm{SiO}_{2}-\mathrm{MgO}-\mathrm{FeO}$ system was about $23 \%$ at $1623 \mathrm{~K}$.

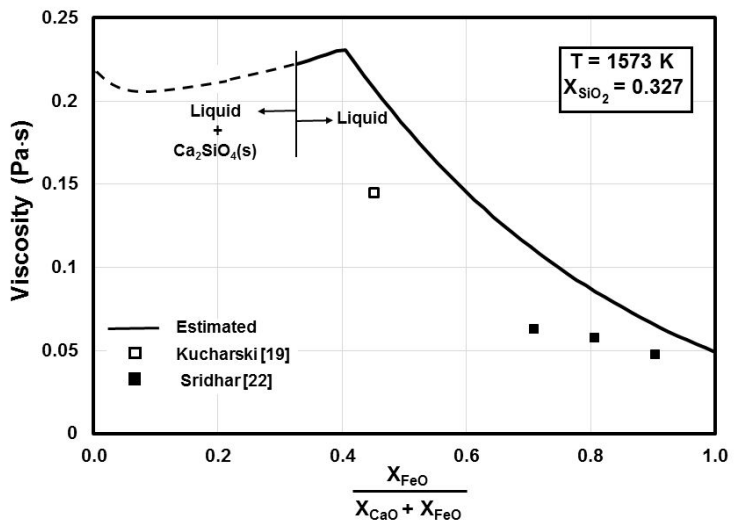

Figure 7. Calculated and experimental ${ }^{(19,22)}$ viscosities in the $\mathrm{SiO}_{2}-\mathrm{CaO}-\mathrm{FeO}$ system at $1573 \mathrm{~K}$ and $\mathrm{X}_{\mathrm{SiO} 2}=0.327$.

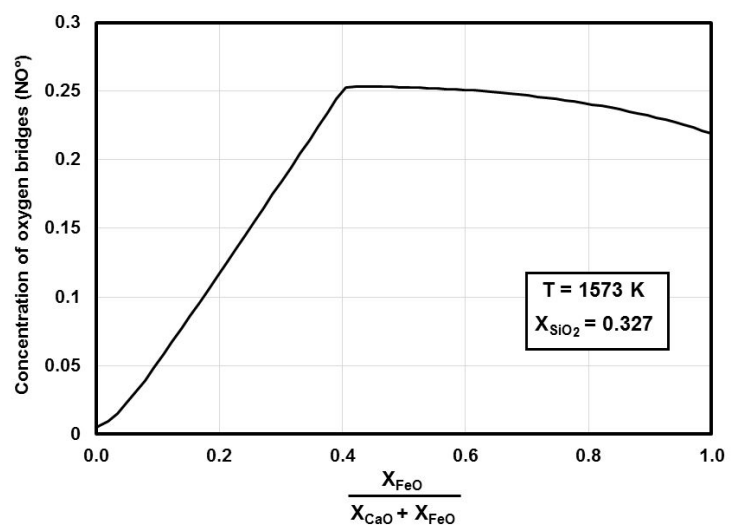

Figure 8. Concentration of oxygen bridges in the $\mathrm{SiO}_{2}-\mathrm{CaO}-\mathrm{FeO}$ system calculated by the structural model at $1573 \mathrm{~K}$ and $\mathrm{X}_{\mathrm{SiO} 2}=0.327$.

We tried to make the viscosity model as simple as possible and included only three parameters for each binary system, two parameters for the temperature function, and one for the composition function. This model estimates the viscosity of ternary systems by combining the results of the binary systems. The model considers that the viscosity of the ternary systems cannot be linearly extrapolated from the results of the binary system. However, a more complete model for ternary systems $\left(\mathrm{SiO}_{2}-\mathrm{AO}-\mathrm{BO}\right)$ would be obtained if the broken bridges for the $\mathrm{AO}$ and $\mathrm{BO}$ species and the free oxygen were taken into account besides the non-bridging oxygen.

The adjusted parameters used in this model were calculated using the temperatures (between $1573 \mathrm{~K}$ and $1723 \mathrm{~K}$ ) and compositions $\left(0.2<\mathrm{X}_{\mathrm{SiO} 2}<0.5\right)$ of the experimental results reported in the literature; following this, the slag viscosity can be properly described by the actual model in the range of temperatures and compositions above mentioned. More experimental data are needed for further assessment of the model parameters.

To conclude, the model proposed in this study links melt composition, structure and thermodynamic properties. The structural model used in this work has been extended to predict other properties, such as molar volume, phase diagrams, sulphide capacity and all the thermodynamic properties of binary and ternary silicate systems. 


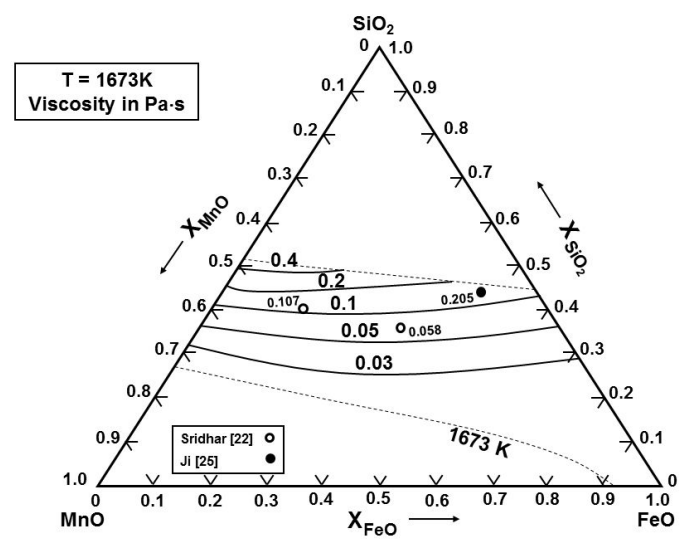

Figure 9. Isoviscosity curves $(\mathrm{Pa} \cdot \mathrm{s})$ of $\mathrm{SiO}_{2}-\mathrm{MnO}-\mathrm{FeO}$ melts at $1673 \mathrm{~K}$.

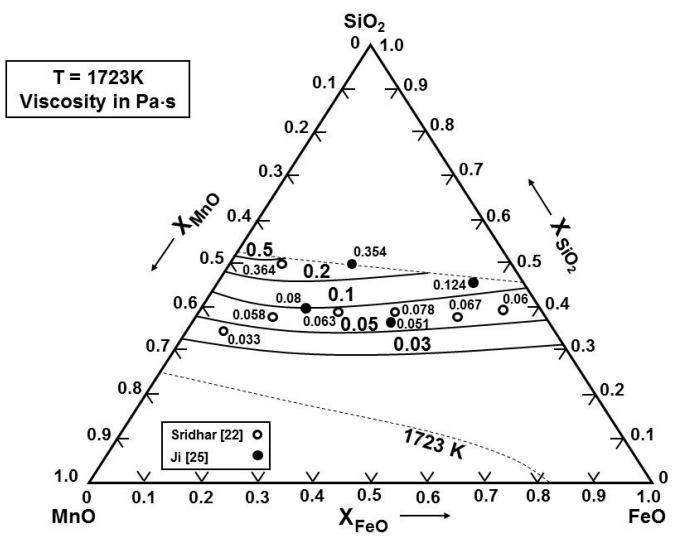

Figure 10. Isoviscosity curves $(\mathrm{Pa} \cdot \mathrm{s})$ of $\mathrm{SiO}_{2}-\mathrm{MnO}-\mathrm{FeO}$ melts at $1723 \mathrm{~K}$.

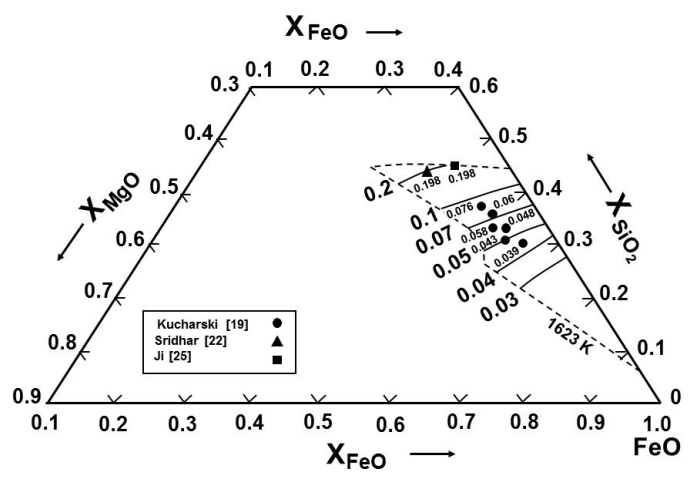

Figure 11. Isoviscosity curves $(\mathrm{Pa} \cdot \mathrm{s})$ of $\mathrm{SiO}_{2}-\mathrm{MgO}-\mathrm{FeO}$ melts at $1623 \mathrm{~K}$.

\section{Conclusions}

A structure-related model for the viscosity of silicate melts has been extended to $\mathrm{FeO}$ containing systems by considering a directly dependent viscosity with the oxygen bridges $\left(\mathrm{O}^{\circ}\right)$, which was calculated by a structural thermodynamic model. The viscosity of the system $\mathrm{SiO}_{2}-\mathrm{FeO}$ was estimated in the present work. A good agreement with mean deviation less than $12 \%$ was achieved for the comparison of the estimated and available experimental values.
The model is capable of predicting the viscosity of the ternary systems $\mathrm{SiO}_{2}-\mathrm{CaO}-\mathrm{FeO}, \mathrm{SiO}_{2}-\mathrm{MnO}-\mathrm{FeO}$ and $\mathrm{SiO}_{2}-\mathrm{MgO}-\mathrm{FeO}$ by using binary parameters. The model also considers the effect of the content of the different metal oxides in the silicate structure through the value of the oxygen bridges calculated with the thermodynamic model for ternary systems. The present model provides a good representation for most of the experimental data in these systems.

\section{Acknowledgements}

The authors wish to thank the Institutions CONACyT, SNI, COFAA and IPN for the support of this research.

\section{References}

1. Keskinkilic E, Pournaderi S, Geveci A, Topkaya YA. Use of colemanite in ferroniquel smelting. J. Min. Metall. Sect. B-Metall. 2019;55(1):1-8. http://dx.doi.org/10.2298/JMMB181009007K.

2. Riboud PV, Roux Y, Lucas D, Gaye H. Improvement of continuous casting powders. Fachber. Huttenprax. Metallweiterverarb. 1981;19:859-67.

3. Urbain G. Viscosity estimation of slags. Steel Res. 1987;58(3):1116. http://dx.doi.org/10.1002/srin.198701513.

4. Reddy RG, Hebbar K. Viscosity of $\mathrm{FeO}-\mathrm{SiO}_{2}$ slags. Miner Metall Process. 2001;18:195-9.

5. Shu Q, Wang L, Chou KC. Estimation of viscosity for some silicate ternary slags. J. Min. Metall. Sect. B-Metall. 2014;50:13944.

6. Le Losq C, Neuville DR. Molecular structure, configurational entropy and viscosity of silicate melts: link through the Adam and Gibbs theory of viscous flow. J Non-Cryst Solids. 2017;463:17588. http://dx.doi.org/10.1016/j.jnoncrysol.2017.02.010.

7. Kondratiev A, Jak E. A quasi-chemical viscosity model for fully liquid slags in the $\mathrm{Al}_{2} \mathrm{O}_{3}-\mathrm{CaO}-{ }^{-} \mathrm{FeO}$ '- $\mathrm{SiO}_{2}$ system. Metall Mater Trans, B, Process Metall Mater Proc Sci. 2005;36(5):623-38. http://dx.doi.org/10.1007/s11663-005-0053-9.

8. Romero-Serrano A, Pelton AD. Extensions of a structural model for binary silicate systems. Metall Mater Trans, B, Process Metall Mater Proc Sci. 1995;26(2):305-15. http://dx.doi.org/10.1007/ BF02660973.

9. Gutiérrez J, Romero-Serrano A, Plascencia G, Chávez F, Vargas R. Thermodynamic model for ternary silicate systems. ISIJ Int. 2000;40(7):664-9. http://dx.doi.org/10.2355/isijinternational.40.664.

10. Romero-Serrano A, López-Rodríguez J, Hernández A, PérezLabra M, Cruz-Ramírez A. Evaluation of molar volume of silicate systems using a structural model. Glass Phys Chem. 2019;45(3):195-201. http://dx.doi.org/10.1134/S1087659619030088.

11. López-Rodríguez J, Romero-Serrano A, Hernández-Ramírez A, Pérez-Labra M, Cruz-Ramírez A, Rivera-Salinas E. Use of a structural model to calculate the viscosity of liquid silicate systems. ISIJ Int. 2018;58(2):220-6. http://dx.doi.org/10.2355/ isijinternational.ISIJINT-2017-483.

12. Wu G, Seebold S, Yazhenskikh E, Hack K, Müller M. Viscosity model for oxide melts relevant to fuel slags. Part 3: The iron oxide containing low order systems in the system $\mathrm{SiO}_{2}-\mathrm{Al}_{2} \mathrm{O}_{3}-$ $\mathrm{CaO}-\mathrm{MgO}-\mathrm{N}_{2} \mathrm{O}-\mathrm{K}_{2} \mathrm{O}-\mathrm{FeO}-\mathrm{Fe}_{2} \mathrm{O}_{3}$. Fuel Process Technol. 2018;171:339-49. http://dx.doi.org/10.1016/j.fuproc.2017.09.002.

13. Wu G, Seebold S, Yazhenskikh E, Tanner J, Hack K, Müller M. Slag mobility in entrained flow gasifieres optimized using a new reliable viscosity model of iron oxide-containing multicomponent melts. Appl Energy. 2019;236:837-49. http:// dx.doi.org/10.1016/j.apenergy.2018.11.100.

14. Myslevic T, Wozniak J, Verny V. Sbornik Vedeckych Praci Vysoke Skoly Banske v Ostrave. Rada Hutnicka. 1974; 20(2): 57-67. 
15. Zhang L, Jahanshahi S. Review and modeling of viscosity of silicate melts: Part II. Viscosity of melts containing iron oxide in the $\mathrm{CaO}-\mathrm{MgO}-\mathrm{MnO}-\mathrm{FeO}-\mathrm{Fe}_{2} \mathrm{O}_{3}$ system. Metall Mater Trans, B, Process Metall Mater Proc Sci. 1998;29(1):187-95. http://dx.doi.org/10.1007/s11663-998-0021-2.

16. Röntgen P. Struktur und Eigenschaften von Schlacken der Metallhütten-prozesse, Winterhager H, Kammel R. Erzmetallurgy. 1956;9:207-14.

17. Shiraishi Y, Ikeda K, Tamura A, Saitô T. On the viscosity and density of the molten FeO- $\mathrm{SiO}_{2}$ system. Trans. JIM. 1978;19(5):26474. http://dx.doi.org/10.2320/matertrans1960.19.264.

18. Chen M, Raghunath S, Zhao B. Viscosity measurements of "FeO"- $\mathrm{SiO}_{2}$ slags in equilibrium with metallic Fe. Metall Mater Trans, B, Process Metall Mater Proc Sci. 2013;44(3):506-15. http://dx.doi.org/10.1007/s11663-013-9810-3.

19. Kucharski M, Stubina NM, Toguri JM. Viscosity measurements of molten $\mathrm{Fe}-\mathrm{O}-\mathrm{SiO}_{2}$, $\mathrm{Fe}-\mathrm{O}-\mathrm{CaO}-\mathrm{SiO}_{2}$, and $\mathrm{Fe}-\mathrm{O}-\mathrm{MgO}-\mathrm{SiO}_{2}$ slags. Can Metall Q. 1989;28(1):7-11. http://dx.doi.org/10.1179/ cmq.1989.28.1.7.

20. Urbain G, Bottinga Y, Richet P. Viscosity of liquid silica, silicates and alumino-silicates. Geochim Cosmochim Acta. 1982;46(6):106172. http://dx.doi.org/10.1016/0016-7037(82)90059-X.

21. Dingwell DB. Redox viscosimetry of some Fe-bearing silicate melts. Am Mineral. 1991;76:1560-2.

22. Sridhar S, Sichen D, Seetharaman S, Mills KC. Viscosity estimation models for ternary slags. Steel Res. 2001;72(1):310. http://dx.doi.org/10.1002/srin.200100073.

23. Ji F-Z, Sichen D, Seetharaman S. Experimental studies of the viscosities in the $\mathrm{CaO}-\mathrm{Fe}_{\mathrm{n}} \mathrm{O}-\mathrm{SiO}_{2}$ slags. Metall Mater Trans, B, Process Metall Mater Proc Sci. 1997;28(5):827-34. http:// dx.doi.org/10.1007/s11663-997-0010-x.

24. Johannsen F, Wiese W. Erzmetallurgy. 1958;11:1-15.

25. Ji F-Z, Sichen D, Seetharaman S. Experimental studies of viscosities in $\mathrm{Fe}_{\mathrm{n}} \mathrm{O}-\mathrm{MgO}-\mathrm{SiO}_{2}$ and $\mathrm{Fe}_{\mathrm{n}} \mathrm{O}-\mathrm{MnO}-\mathrm{SiO}_{2}$ slags. Ironmak Steelmak. 1998;25:309-16. 